Ankara Üniversitesi Türk Inkulâp Tarihi Enstitüsü Atatürk Yolu Dergisi S 41, Mayss 2008, s. 105-123

\title{
Türk-Yunan İlişkileri ve Megali İdea
}

\section{Dr. Oğuz KALELIOĞLU}

\section{ÖZET}

Bu makalede Coğrafya 'nın komşu yaptığı, tarihin düşman kıldığı, Türkiye ve Yunanistan'ın ilişkileri ve Megali İdea (Büyük İdeal-Büyük Yunanistan) doktrini özet olarak incelenmiştir. Amaç; kalıcı bir Türk-Yunan Barışını sağlamaktır.

İlmin tarafsızlı̆̆ ile yaptlan inceleme sonucunda; iki ülke arasındaki ihtilafların kaynağında Yunanistan'ın Megali İdea fikrinin olduğı görülmektedir. Çünkü; Megali İdea'nın bütün hedefleri doğudadır ve Türkiye topraklart ïzerindedir. Megali İdea, sadece Anadolu'yu tahrip etmekle ve Türk milletine acılar vermekle kalmamıș, aynı zamanda Yunan Ordusuna ve halkına da felaket getirmiştir.

Yunanistan günümüzde savaşla değil, fakat psikolojik harple Megali İdea hedeflerine ulaşmak istemektedir. Tarihin, yaşanan acı tecrübelerine rağmen. Yunanistan' in Megali İdea 'yı terk etmemesi çok önemli bir konudur. Ancak; Megali İdea 'ya rağmen Türk-Yunan Barışı sağlanmalıdır. Kalıcı bir Türk-Yunan Barışı, her iki komşu halkın yararınadır. Zaman zaman bozulan Türk-Yunan İlişkileri, Atatürk döneminde kalıcı barışa kavuş̧muştur.

Bu tez'in ortaya çıkardığı gerçek; Türk-Yunan Barışının kalıcı olabilmesi için en önemli şart, Atatürk 'ün dediği gibi. Türkiye 'nin Yunanistan' ' barışa zorlayacak gücü her zaman muhafaza etmesidir.

Anahtar kelimeler: Yunanistan, Megali İdea, Ellada Sipna (Yunanistan Uyan). 


\section{Turkısh-Greek Relationships and Megali Idea}

\section{ABSTRACT}

In this article; as a summary, examined Turkish-Greek relationships which two countries made neighbour by geography, enemy by history and Megali Idea (Great Idea-Great Greek) doctrine. Aim is to reach a lasting peace between Turkish-Greek. By impartiality of the science, according to the end of the research; Megali Idea is the main source of the conflict between two countries Because, all the objects of the Megali Idea are at the east and always on the Turkish territory.

Not only Megali Idea devastated with Anatolia painfully, but also caused catastrophe of the Greek Army and Greek people. Greek wants to reach objects of the Megali Idea, not war, but by pschological warfare today.

Despite lived sadness experience in history. The Greek didn't leave Megali Idea Doctrin, the most important matter. In space of Megali Idea, Turkish-Greek Peace must be accomplished, Lasting peace is beneficial for both nations.

Turkish-Greek relations which broke time to time reached a lasting peace at Ataturk's period.

In this article, the fact which is discovered is that Turkey must keep enough power to remain Turkish-Greek lasting peace.

Key words: Greek, Megali Idea, Ellada Sipna (Greek Wake Up).

GIRIŞ:

Coğrafyanın komşu yaptığı, tarihin düşman kıldığı bu iki ülkenin İlişkilerini ve Yunanistan'ın Megali İdea (Büyük Yunanistan) fỉkrini inceleyerek ilmi bir sonuç çıkarmak üzere hazırlanan bu makale, tarafsız bir gözle ve tamamen tarihi gerçeklere dayanarak kaleme alınmıştır.

Evvela Yunan deyince, tarihteki eski Yunanlılar ve Yunan kültürü akla gelmektedir. Halbuki; Yunanlıların, menşe-i hakkında çalışmalar yapan Alman tarih profesörü Jakep Philpp Fallmerayer (1791-1861) "Bizans Tarihi” adlı eserinde, günümüzdeki Yunanlıların Antik Yunan ırkından gelmediklerini, Slav ve Arnavut asıllı olduklarını kaydetmektedir. ${ }^{2}$

Diğer yandan yazar ve Yunan tarih Profesörü, Konstandinos Paparrighopulos (1851-1891)'da 1872 yılında yayınladığı ünlü “Antik Çăgdan Günümüze Yunan Halkının Etnik Tarihi (Epilogos Tis İstorias Tu

\footnotetext{
${ }^{1}$ Meydan Larousse,Büyük Lûgat ve Ansiklopedi, Istanbul, 1971, C.4, s.501.

${ }^{2}$ Encylopedia Britannica, U.S.A, 1970, c.9, s.51.
} 
Elliniku Ethnus)"3 adlı eserinde; "Safkan (Eski ) Yunanlılar M.S. 146'da Romalıların Korent' $i$ işgal ve tahrip etmeleri ile yeryüzünden silinmişlerdir. M.S. 6 nc1 yüzyılda kuzey ve batıdan Yunan yarımadasına akan Slav, Arnavut ve Ulahlar bölgeye yayılmışlardır." ${ }^{4}$ demektedir.

Bugünkü Yunanlıya bütün dünya, Grek-Greece demektedir. Grek, Slavca bir kelime olup; "Hilekâr, dolandırıcı" anlamındadır. Bu tanımı Fransızların ünlü Ansiklopedileri Larousse XX. Siele'in 1930 tabının III.cilt 867 sahifesinde görüyoruz.

Osmanlı İmparatorluğu, kullandığı diplomatik lisanında diğer milletleri yüceltmiş; Arap'a Kavmi Necip (Asil Kavim) dediği gibi, Grek'e de İyon'a izafeten Yunan, Halkına da Roma'dan gelen anlamında Rum demiștir.

Günümüzde de Türk halkı aynı geleneği devam ettirerek, Grek’e Yunan, halkınada Rum demektedir.

Türk-Yunan ilişkileri, farklı değerlendirilmelerle farklı zamanlara uzanmaktadır. Yunanlıların, kendilerinin Bizans (Doğu Roma) İmparatorluğunun devamı oldukları iddialarına bakılırsa; bu ilişki, Türklerin Anadolu'yu fethettiği tarih olan 1071 'den itibaren 937 yıl, yani 10 asrı bulmakta, bugünkü Yunanistan'ın bağımsız bir devlet olarak ortaya çıkışı olan 1830 'dan itibaren alınırsa, bu ilişkiler 178 yıl, yani 2 asıra kadar gitmektedir.

Selçuklulardan sonra Anadolu'da hâkimiyet kuran Osmanlının1362'de Edirne'yi fethi ile başlayan Bizansı kuşatması 1453 yılında Fatih'in İstanbul'u almasıyla son bulmuş ve 1830 'da Yunanistan'ın bağımsızlığına kadar tam 377 yıl Ortodoks Rum ahali, Osmanlı tebaası olarak yaşamıştır.

Osmanlı İmparatorluğu'nun üç kıtayı kaplayan geniş coğrafi hudutları içinde değişik din, ırk ve dillere sahip topluluklar gibi Rumlarda Osmanlı vatandaşı olarak hiçbir baskı görmeden huzur ve güven içinde yaşıyorlardı. Devletin hukuk sistemi, bu değişik etnik ve dini yapıyı güçlü bir ideal ve müşterek bir şuur etrafında toplamaya göre tanzim edilmişti.

Bu müşterek şuur, "Osmanlılık şuuru" idi. Kullanılan hukuk sisteminde devlet yönetimine ve ordu idaresine ait hususlar Türklerin Orta Asya'dan beri uyguladıkları örfi hukuka, aile ve fertler arasındaki ilișkiler șer-i hukuka, gayri Müslim tebaanın kendi aralarındaki sorunları ise cemaat

${ }^{3}$ Büyük Larousse Sözlük ve Ansiklopedisi, Gelişim Yayınlan A.Ş. İstanbu, 1986, Cilt: 15 , s.9149.

${ }^{4}$ Cem Başer, Yunan Oyunu, İstanbul- 1988, s.27; Mehmet Uysal, Aldatma ile Örtülen Yunan Yayılması, Harp Akademisi Basımevi, İstanbul-1996. 
(kilise) hukukuna bağlı idi. Osmanlı Devleti; devlete ve müesseselerine işlerlik kazandırmaya çalışırken şer-i ve örfi hukuk sistemlerini kullanmıştır. Devlet yönetimine ve askeri yönetime ait hususlarda daha çok örfi hukuka yer vermiştir. Böylece Osmanlı devleti her iki sistemi kaynaştırarak kendisine has bir "Osmanlı hukuku" meydana getirmeye çalışmıştır."

\section{Megali İdea (Büyük Yunanistan) Fikri}

Megali İdea; Yunanca "Büyük Fikir", "Büyük Ülkü” anlamına gelmektedir. Yunan hedefleri olarak belirlenen Megali İdea, aslında; 1798'den itibaren bu ideal peșinde koşan Yunanlıların emperyalist politikalarının amacıdır.

Megali İdea, ortaya atıldığı zaman, "Bağımsız Yunanistan"ın, daha doğrusu "Büyük Yunanistan"ın, "Yunan İmparatorluğu"nun, "Bizans İmparatorluğu"nun, Yunanlılık adı altında bir "Kültür İmparatorluğu”nun kurulmasını öngören bir anlamda kullanılmıştır.

Yunanlıların Megali İdeası; İstanbul'un (Konstantinopolis) merkezini oluşturduğu Bizans-Yunan İmparatorluğu'nun canlandırılması, Doğu Roma İmparatorluğunun topraklarının Yunan Krallığı'na katılması düşüncesidir.

Bu düşüncenin isim babası, Yunanistan'daki Fransız yanlısı kesimin başı olan İoannis Kolettis, Yunan Meclisinde yaptığı konuşmada:

"Yunanistan Krallığı, Yunanistan değildir. Yunanistan'ın sadece bir parçası, en küçük, en yoksul bir parçasıdır. Yunanlılar, sadece krallık içinde oturanlar değillerdir, aynı zamanda Yanya'da ya da Selanik'te, Serez'de ya da Edirne'de, İstanbul'da ya da Trabzon'da, Girit ya da Sisam Adası'nda, Yunan Tarihine ya da Yunan ırkına bağlı bașka yerlerde oturanlar da Yunanlıdır. Helenizm'in iki büyük merkezi vardır: Krallığın başkenti Atina'dır, İstanbul (Kostantinopolis), büyük başkent, bütün Yunanlıların kenti, düşü, umududur" $^{\text {" }}$ demiştir.

Etniki Eterya (Azınlıkların Birliği) ve daha sonra Filiki Eterya adını alan Cemiyet, İpsilanti, Ksantos ve Çakalof tarafindan kurulmuştur.

Megali İdea'nın Hedefleri ;

Filiki Eterya kurulurken hazırlanan program, Megali İdea'nın hedefleri olmuştur. Bu hedefler şöyle suralanabilir:

(1) Yunan Milletinin tam istiklalinin temini,

(2) Bat1 Trakya ve Selanik'in Yunanistan'a ilhak1,

\footnotetext{
${ }^{5}$ Bayram Kodaman, II nci Abdülhamit Devri Doğu Anadolu Politikası. Ankara, 1987, s.

${ }^{6}$ Michael Llewellyn Smith, Yunan Diüsü, Ayraç Yayınlan, Ankara 2002, s.17
} 
(3) Ege Adaları'nın Yunanistan'a ilhak1,

(4) Oniki Ada'nın Yunanistan'a ilhakı,

(5) Girit Adası'nın Yunanistan'a ilhakı,

(6) Batı Anadolu'nun Yunanistan'a ilhakı,

(7) Pontus Rum Hükümetinin kurulması,

(8) Kıbrıs'ın Yunanistan'a ilhakı,

(9) İmroz ve Bozcaada'nın Yunanistan'a ilhakı,

(10) İstanbul'un işgal edilerek Doğu Roma İmparatorluğu'nun ihyası.

Ksanto'nun Fener'deki evi merkez olarak kullanılmaya başlandı. Cemiyet liderliği için ilk düșünülen Rus Dıșișleri Bakanlığı'nı yürüten Kapodistirias kabul etmeyince, liderliğe Aleksandr İpsilanti getirildi. 12 Nisan 1820 'de A.İpsilanti'nin Umumi Nazır tayin edildiğine dair bir senet düzenlenerek imzalandi. ${ }^{7}$

Bu dönemde Cemiyet; Selanik, Tırhala, Çamlıca, Mora, Eflak, Buğdan, Kudüs, İskenderiye, Ege Adaları, İstanbul, Anadolu sahilleri, Bükreş ve Moskova'da şubeler açmıştı. Türkiye'deki şubeleri Rum ticaret şirketleri maskesi altında çalışıyordu.

Eterya'nın faaliyetlerinin yürütülmesinde kiliselerin de büyük rolü oldu. Çünkü kiliseler kendilerine verilen imtiyazlar sebebiyle denetlenemiyordu.

Yapılan aramalarda, kiliselerin silah deposu haline getirildiği, silahların tabutlar içerisine yerleştirildiği görülmüştü. ${ }^{8}$

İstanbul'daki Patrikhane, 1814 'den itibaren bu cemiyetin merkezi halinde çalışmıştır. Patrik Grigoryas da cemiyetin üyesiydi. ${ }^{9}$

Osmanlı bünyesindeki Hıristiyan azınlıklar büyük devletler tarafından kendi gizli maksatları için paylaşılmış bulunuyordu. Rusya, İstanbul ve Boğazlar ile Doğu illerini ele geçirmek için Ortodoks ve Gregoryen Hıristiyanları kullanıyor; İngiltere, Ortadoğu, Mısır, Arabistan ve Irak’taki etkisini koruyup yaymada Protestanları alet ediyor; Fransa ise Çukurova, Lübnan ve Suriye'deki çıkarları için Katolik Gregoryenleri kullanıyordu.

7 M. Murat Hatipoğlu; Yunanistan'daki Gelişmelerin Işığında Türk-Yunan İlişkilerinin 101 Yilı, (1821-1922), TKAE Yayım, Ankara,1988, s.3.

8 Süleyman Kocabaş, Tarihte ve Günümüzde Türk-Yunan Mücadelesi, Bayrak Yayınları, Istanbul., 1984,s.52

9 Sadrazam Kamil Paşa; Tarih-i Siyasi Devlet-i Aliye-i Osmaniye. Matbaa-i Ahmed Ihsan, Istanbul,1325, c.3 s.56. 
Böyle bir ortamda, Filiki Eterya'nın çalışmaları sonucunda Rumlar, yıllardır silahlanıyor ve isyan için firsat kolluyorlardı. Ancak, 1788'den beri Yanya Valiliğinde bulunan Tepedelenli Ali Paşa'dan çekiniyorlar ve bir an evvel ondan kurtulmaya çalışıyorlardı.

Ali Paşa, Rumların sinsi faaliyetlerini takip ediyor, bütün amaç ve faaliyetlerini ögrenerek belgeleriyle, kararlarıyla Bab-1 Ali'ye bildiriyordu. Ancak Ali Paşa ile Sultan II. Mahmut'un arası, içinde Rum Halet Efendinin parmağının da bulunduğu, İstanbul Fener Patrikhanesi ve Saray arasında çevrilen entrikalar sonucunda açılmıș ve Ali Paşa isyan etmiștir. ${ }^{10}$

Tepedelenli Ali Paşa 1820 yılında devlet kuvvetleriyle çatışmaya girdi. Onu tenkil için Hurşit Paşa, Mora'daki askeri de yanına alarak Yanya üzerine yürüdü ve Ali Paşa intihar etti.

Rumları sıkı bir şekilde takip ederek göz açtırmayan Tepedelenli Ali Paşa'nın, Rumlar'ın entrikalarıyla ortadan kalkması sonucu, Megali İdea'nın eylem safhası başlamış oldu. İlk hedef olan Yunan İsyanı başlatıldı ve Megali İdea günümüze kadar daima Türklerin aleyhine işletildi.

\section{Megali İdea'nın Kat ettiği Mesafe}

Megali İdea fikrinin tarih sahnesine çıkışından günümüze kadarki faaliyeti incelenirse ana hedefinin Türkiye aleyhine genişlemek olduğu kolayca görülür.

Yunanistan, belki askeri alanda değil ama siyasi alanda ve bilhassa dış politikasını destekleyen propaganda alanında son derece başarı ile Megali İdea'nın hedeflerinden birkaçı hariç, hemen tamamını gerçekleştirmiş ve daima Türkiye aleyhine genişlemiştir.

\section{Yunan Milletinin Tam İstiklalinin Temini}

1821 yılında başlayan Yunan İsyanı, Avrupa devletlerininde yardımıyla hedefine ulaşmış ve dört buçuk asır süren Osmanlı - Türk egemenliği Yunanistan'da sona ermiştir. Osmanlı devleti güçlü iken bunun olacağı hayal bile edilemezken Megali İdeanın ilk hedefi böylece gerçekleşmiştir.

\section{Batı Trakya ve Selanik'in Yunanistan'a İlhak1:}

Balkan harbi esnasında (1912 - 1913) bu madde'de gerçekleșmiş Batı Trakya ve Selanik Yunanistan'a katılmıştır.

\section{Ege Adalarının Yunanistan'a İlhakı;}

Balkan harbinin içinde,

10 M.Süreyya Şahin, Fener Patrikhanesi ve Türkiye, Istanbul-1980, s. 135. 
Limni

Taşoz

Semendirek

Midilli

Sakız

Sisam

Nikariya
22 Ekim 1912'de

31 Ekim 1912'de

1 Kasım 1912'de

2 Ocak 1913'de

3 Ocak 1913'de

16 Mart 1913'de

17 Kasım 1913'de

Yunanlılar tarafından işgal edilmiştir. Bu adaların ilk dördü 1456 yılında Fatih Sultan Mehmet zamanında fethedilmiş tam 456 yıl Osmanlı Devleti hâkimiyetinde kalmıştı.

Gökçeada (İmroz) ve Bozcaada'nın Yunanistan'a İlhakı:

Balkan harbinden sonra,

Gökçeada (İmroz)

31 Ekim 1912

Bozcaada

7 Kasım 1912'de

Yunanlılar tarafından işgal edilmiş, ancak Büyük Taarruz'dan sonra 24 Temmuz 1923 yılında Lozan Antlaşması ile Yunanlılardan geri alınmıştır.

Oniki Adanın Yunanistan'a İlhakı;

Yunanlıların diğer bir Megali İdea hedefi olan 12 Ada'da, Girit'in akıbetine uğramıștır. II. Dünya Harbi sonunda Almanlar yenilince işgal ettiği adaları boşaltmışlardır. Yunanlılar başta Rodos olmak üzere 12 adayı 10 Şubat 1947 tarihinde işgal ve ilhak ederek Megali İdea'nın bu maddesini de gerçekleştirmişlerdir.

Girit Adasının Yunanistan'a İlhakı;

Ege Denizinin en büyük adası olan Girit, ilk defa Osmanlı İmparatorluğu tarafından 1644 yılında kuşatılmış 25 yıl aralıklarla süren çetin muharebeler sonunda 1669 yılında tamamen fethedilmiştir. Megali İdea'nın hedefleri içerisinde Girit'i ele alan Yunanistan, Girit'i, Enosis (Yunanistan'a ilhak) yapmak için Kıbrıs'takine benzer çalışmalar yapmış, yürüttügü yoğun propagandalarla Avrupa ülkelerini ikna ederek Osmanlı Devletine "Girit meselesini çözün" baskısını yaptırmıştır. 
1897 Türk - Yunan harbinde Yunanlılar Dömeke'de ağır bir yenilgiye uğramalarına rağmen başta İngiltere olmak üzere batılı devletlerin araya girmeleri ve Osmanlı Devletine ağır baskılar yapmaları sonucu Girit Adası Osmanlı Devleti'nden kopartılarak bağımsızlığını kazandı ve Megali İdea'nın bu maddesi, 14 Kasım 1913'de, Yunanistan'ın Girit'i işgali ile hedefine ulaşmış oldu.

\section{Kıbrıs'ın Yunanistan'a İlhakı;}

Kıbrıs'1 Türkiye'nin yumuşak karnında gören ve Girit'ten sonra Megali İdea'nın en önemli hedeflerinden sayan Yunanistan, uzun yıllar Kıbrıs' 1 Yunanistan'a ilhak etmek (Enosis) için yoğun çalışmalar yapmıștır.

Kıbrıs'la ilgili ilişkilerin en önemli özelliği ise; Kıbrıs'ın hem Megali İdea'nın hedefi olması, hem de İngiliz idaresinde bulunmasına rağmen, Kıbrıs Türk'ünü, Anadolu'daki Milli Mücadeleyi yakından takip ederek ve Atatürk İlke ve İnkılâplarını kendi kendine uygulayarak milli şuurunu ve adadaki Türk varlığını günümüze kadar muhafaza etmiş olmasıdır.

Son olarak, 15 Temmuz 1974'de Nikos Sampson darbesi ile Enosis'e teșebbüs edilmiş ancak Türkiye'nin Kıbrıs Barıș Harekâtını gerçekleştirmesi ile yani Türk ordusunun fiilen savașa girmesiyle bu teșebbüs akamete uğratılmıştır.

\section{Batı Anadolu'nun Yunanistan'a İlhak1;}

30 Ekim 1918 tarihinde Osmanlı Hükümetinin imzaladığ1 Mondros Mütarekesine göre; Yunanlılar 15 Mayıs 1919'da İzmir'e çıkmışlar ve Anadolu'nun içerisine ilerleyerek Anadolu Türklüğünü yok etmek üzere Ankara'ya dayanmışlardır. 3 yıl süren Batı Anadolu işgal ve ilhakı Türk milletinin Mustafa Kemal Paşa'nın önderliğinde verdiği ölüm kalım savaşı sonunda püskürtülmüș ve kaybedilen Batı Anadolu geri alınabilmiștir.

\section{Pontus Rum Devleti'nin Kurulmasi;}

Mondros Mütarekesinden sonra Pontus Rum çeteleri, Yunanistan'dan aldıkları talimat, Fener Rum patrikhanesinin organizesi, Rusların ve Merzifon'daki Amerikan kuruluşlarının destekleriyle silahlı faaliyete başladılar. Samsun'dan Batum'a kadar Doğu Karadeniz Bölgesi'nde 25000 kișilik bir güce ulaşan Pontus çeteleri, Müslüman halkı katlediyor ve bölgede Yunanistan'la bağlantılı Pontus Rum Devletinin kurulmasına çalışıyorlardı. TBMM'nin çıkardığı kanunla Nurettin Paşa'nın komutasında teşkil edilen 
Merkez Ordusu, Karadeniz Bölgesini Pontus Çetelerinden temizlemiş ve Pontus Devleti kurma gayretlerini boşa çıkarmıştır ${ }^{11}$

\section{İstanbul'un İșgali ve Bizans İmparatorluğu'nun Yeniden İhyası;}

Mondros Mütarekesine göre İstanbul'da 16 Mart 1920'de İtilaf Devletleri tarafından işgal edildi. İtilaf Devletleri adına Fransız General Frenchet de'Esprey beyaz bir atın üzerinde Karaköy de karaya çıkınca İstanbul'daki Rumlar, Galata köprüsünden Bankalar Caddesine kadar yerlere Türk bayraklarını serdiler ve işgal kuvvetlerine aziz Türk bayraklarını çiğnettiler. Yunanlılar da diğer ordularla beraber İstanbul'a çıktılar. Eyüp ve Fener bölgelerini işgal ettiler. Megali İdeanın, hayallerini süsleyen, son maddesini çılgın bir taşkınlıkla gerçekleştirdiler. Ancak Büyük Taarruz'dan sonra İstanbul'u terk etmek zorunda kaldılar.

\section{Yunanistan Megali İdea'dan Vazgeçebilir mi ?}

Yunan siyasi ve askeri karar organları Megali İdea'dan vazgeçerler mi?

Bu soruya cevap teşkil eden bazı olayları inceleyelim.

\section{1.-Büyük Taarruzdan sonra;}

$\mathrm{Bu}$ soruya en güzel cevap; Büyük Taarruzdan sonra, Yunan Kralı Konstantin'in yeğeni ve Anadolu'ya çıkan Yunan Ordusunda kolordu komutanı olan Prens Andre'nin yazdığı "Felakete Doğru" isimli kitapta verilmektedir.

Prens Andre, "Felakete Doğru" isimli kitabında; "Küçük Asya'da ki bu fedakârlık boşuna mıdır?" diye sormakta, sonra:

"Hayır" diye cevaplandırmakta ve şöyle açıklamaktadır;

“Çünkü Yunan askeri tarafından Anadolu'da ekilmiş olan tohum, günün birinde büyük ve çiçekli bir ağaç halinde açacaktır."demektedir. Yani Prens Andre; iki yüz bin kişilik Yunan Ordusu'nun denize dökülmesine, sonradan Bat1 Anadolu'ya getirilerek yerleştirilen milyonlarca Rum'un kendilerini,denize atarak perişan halde kaçmasına ve. bu sonucu yaşayarak "Felakete Doğru" isimli kitabında işlemesine rağmen, gene de Megali İdea'dan vazgeçilemeyeceğini anlatıyor. ${ }^{12}$

" M.Kemal Atatürk, Nutuk, Atatürk Araştırma Merkezi Yayını, Ankara-1992, s.425427. s.191.

${ }^{12}$ Prens Andre, Felakete Doğru, Erkan-1 Harbiye-yi Umumiye Matbaası, Istanbul-1933, 


\section{2.- Kıbrıs Barış Harekatından sonra;}

Diğer yandan Kıbrıs Barış Harekâtında, Rum Milli Muhafız Ordusu ve Kıbrıs'da bulunan Yunan kuvvetleri TSK'den, Kıbrıs Barış Harekâtında ağır bir darbe yemelerine ve işgallerinde tuttukları adanın yarısını kaybetmelerine ve acele ateşkes istemelerine rağmen; Kıbrıs Rum Cumhurbaşkanı; Klerides yaptığı basın toplantısında gazetecilerin;" Megali İdea artık ortadan kalktımı?", diye sormaları üzerine; "Bu durumda, Megali İdea 50 yıl geriye gitmiștir” demiş,”Megali İdea kalkmıştır.” dememiştir. Yunanistan ve Kıbrıs Rum yönetimi 1974 Kıbrıs Barış Harekatının üzerinden değil 50 yıl, 10 yıl geçmeden, Yunan subaylarını Bekaa Kampında görevlendirmek ve PKK terör örgütünü Türkiye'ye karş1 desteklemek suretiyle, Megali İdea'dan vazgeçmediklerini göstermişlerdir.

Yunanistan Megali İdea'nın diğer hedeflerini de ele geçirmek için yoğun bir gayret içindedir. Ancak; bunu silahlı güç kullanarak değil, psikolojik harp metotlarıyla ve bașka güçleri devreye sokarak yapmak istemektedir.

Yunanistan Psikolojik Harp Operasyonu ;

Bunun en güzel örneği 1984 yılının başlarında ilk baskısı yapılan Ellada Sipna (Yunanistan Uyan) isimli kitaptır. ${ }^{13}$ Yazarı Andreas Dendrinos'dur. Ancak, "Yunanistan Uyan" kitabı her ne kadar Andreas Dendrinos'un adını taşısa da kitabın bir uzmanlar heyeti tarafından yazıldığı, bu heyetin Türkiye'nin stratejik istihbarat etüdünü hazırlayabilecek, psikolojik hassasiyetlerini tesbit edebilecek ve dış politika analizlerini yapabilecek uzmanları ihtiva ettiği değerlendirilmektedir.

Yunanistan'ın; psikolojik harp ve propaganda alanında, Türkiye konularında uzmanlaşmış, bilim adamı, asker, sosyolog, psikolog, tarihçi ve diplomatların görev aldığı bir Psikolojik Harp Teşkilatı olduğu ve etkin çalışmalar yaptığı bilinmektedir.

Başbakan Andreas Papandreu tarafindan Yunanistan'ın Milli Güvenlik Kurulu sayılan "Yunanistan Dış Politika ve Savunma Yüksek Kurulu (KSEA)' ya getirilmiş ve kitapta Türkiye'ye karşı uygulanması tavsiye edilen psikolojik harp operasyonları için tam yetki alınmıştır. Yazar kitabında Türkiye'ye karşı Yunan askeri ve siyasi karar organlarına, Megali İdea'nın tahakkuku için stratejiler belirlemekte ve Türkiye'yi zayıflatıp, parçalamanın pratik yollarını göstermektedir.

13، Ellada Sipna" kitabı, ilk defa yazar tarafindan Yunanistan'dan getirtilerek tercüme edilmiş ve ilgili kuruluşlara verilmiştir. 
Ellada Sipna kitabının önsözünde, "Yunanistan'ın en büyük ve en temel düşmanı Türkiye'dir" demektedir. Hiç bir ittifak ve hiç bir faaliyet bizim Türkiye üzerindeki idealimizi "Megali İdea'yı" engelleyemez. Türkiye'yi zayıflatmadıkça ve parçalamadıkça Elen ırkına kurtuluş yoktur demektedir. Yazar kitabında Türkiye'yi zayıf düşürmenin ve parçalamanın da yollarını göstermektedir.

Ellada Sipna (Yunanistan Uyan) Kitabındaki konular özet olarak:

a.Yunanistan, Türkiye ile asla sıcak bir savaşa girmemelidir. Türkiye nüfus potansiyeli ve kaynaklar yönünden Yunanistan'dan beș misli büyüktür. Ordusu daha güçlüdür. Sıcak bir savașta Türkiye üzerinde Megali İdea'nın gerçekleşmesi mümkün olmadığı gibi bu Yunanistan'a pahalıya mal olur.

O halde ne yapılmalıdır? Türkiye'nin zayıflıkları yani psikolojik hassasiyetleri vardır. Bunlar ele alınmalı ve kullanılmalıdır.

b. En önemli hassasiyet Kürt sorunudur. Kürtlerin isyan etmesi Tanrının Yunanistan'a bir lütfu olacaktır. Bunun için her vasıta kullanılmalı, Kürtçülük hareketi desteklenmeli ve bir Kürt isyanının çıkartılması sağlanmalıdır.

- Bunun için müttefikler aranmalıdır. Ortadoğu'da bu iş için en uygun müttefik Suriye'dir. Hatay'ın acısı ve Türkiye ile su sorunu devam etmektedir. Avrupa'da en iyi müttefik ise İngiltere'dir. Türkler İngiliz İmparatorluğunu yıkmışlardır. Ortadoğu'da en iyi istihbaratı olan ve en eski, en varyasyonlu (değişken) politikayı uygulayan İngilizlerdir, ABD politikasına da Ortadoğu'da yön verme imkânına sahiptirler. İngiltere'yi Türkiye'ye karşı Yunanistan'ın yanında yer aldırmak Yunan diplomatlarının görevidir.

c. Türkiye'deki sol sendika ve öğrenci hareketleri desteklenmeli, Türkiye siyasi ve ekonomik istikrarsızlığa sürüklenmelidir.

(Türkiye'nin 1984 yılında tesbit edilen üç hassasiyetinden biri, Türkiye'deki sol sendika ve öğrenci hareketleri iken, aynı kitabın 1995 yılında yapılan baskısında Türkiye'nin hassasiyetlerinden "sol sendika ve öğrenci hareketleri” komünizmin çökmesi ile çıkarılmış ve yerine Ermeni meselesi alınmıştır.) Ermeni meselesi hakkında ise;

d. “Türkiye'nin yanı başındaki bir Ermeni Cumhuriyeti'nin varlığı istismar edilecek önemli bir konudur." Zira 65 y1l sonra, Ermeni milliyetçiliğinin atağa kalkmış olması, elbette ki bir tesadüf değildir. 
Yunanistan üzerine düşeni yapmalı ve Ermeni Meselesini desteklemelidir" demektedir.

e. Türkiye'nin en güçlü yanı, Atatürk'ün kurduğu Modern Türkiye'nin laik görüntüsüdür.

$\mathrm{Bu}$ imaj silinmelidir. On üç asırdan sonra islamın yeniden dirilişe geçtiği bir gerçektir. Türkiye'de islamın kopmaz bir parçasıdır.

- Bu güne kadar ileri sürülen Kemalizm ve Batılaşma taşra halkı tarafından pek itibar görmemiştir.

- Türkiye'de Humeyni türü İslami bir yönetim olursa İran gibi Türkiye'de ABD'nin ve Batının desteğini kaybedecek ve kalkınmasına müthiş bir darbe yiyecektir.

- Türkiye'de, radikal İslamcilar, tarikatlar desteklenmeli ve İran modeli bir yönetimin kurulması sağlanmalıdır. Böylece Türkiye NATO ve Batı İttifaklarından kopar ve geldikleri Asya içlerine hapsolmaya mahkûm olur.

f. Türkiye ve $\mathrm{AB}$, Yunanistan Türkiye'nin Avrupa birliğine girmesine bütün gücü ile mani olmaya çalışırken, onun laik, modern yüzünün değişmesini ve radikal islamın görüntüsünü taşıyacak bir konuma gelmesini sağlamalıdır.

"Yunanistan Türkiye'nin AB'ye girmesi için hâkim rol oynamalıdır. Türkiye'nin $A B$ 'ye girmek tutkusu iyi kullantmall, Yunanistan'tn vereceği desteğin Türkiye'nin Kıbrıs konusunda vereceği tavize bağlı olduğu ortaya konmalıdir."

- Türkiye'nin bu psikolojik hassasiyetleri kullanılmalı ve Türkiye güçsüz bırakılmalıdır. Yunanistan'ın aleyhine sonuçlanacak Türk-Yunan savaşından kaçınılmalı ve Türkiye'nin bu zafiyetleri Yunanistan ve bulacağı müttefikler tarafindan ne pahasına olursa olsun istismar edilerek Türkiye parçalanmalıdır.

1984 yılının ilk aylarında Yunanistan'da yayınlanan Ellada Sipna (Yunanistan Uyan) kitabının Türkiye'nin hassasiyetlerinin kullanılması konusundaki verdiği taktikler $\mathrm{O}$ günkü Yunanistan Hükümeti tarafindan büyük ilgi ile karşılanmış ve Türkiye'ye karşı düşmanlık hislerini daima canlı tutan Başbakan Andreas Papandreu tarafindan uygulanmaya konmuştur. İlk icraat olarak; Haziran 1984'de Suriye'ye gitmiş ve Suriye Devlet Başkanı Hafız Esad'la buluşmuştur. 
Bu buluşmada, Papandreu; "Hatay'ın Türkler tarafından alınması ile Suriye toprağı gasp edilmiştir. Biz, Yunanistan olarak, propagandamızın geçerli olduğu bütün ülkelerde Hatay'ın size verilmesini destekleyeceğiz. Ancak siz Suriye olarak Türkiye'nin Güneydoğu Anadolu bölgesinde bir Kürt ayaklanması çıkarın T.C. Devletini askeri ve siyasi yönden bu bölgeye angaje edin" (bağlayın) demiştir.

Bu teklif Suriye Devlet Başkanı Hafız Esad tarafından derhal kabul görüyor ve Suriye, terör örgütü için Beka vadisinde ve Türkiye hudutları boyunca kamp yerleri veriyor.

Yunanistan'da Selanik ve Atina yakınlarında PKK terör örgütü için Lavrion başta olmak üzere kamplar açıyor.Yunan Özel Kuvvetler eski komutanı Korgeneral Dimitri Matafias başkanlığında emekli ve muvazzaf 200 Yunan subayı Suriye'deki Bekaa kampında PKK teröristlerine askeri eğitim yaptırıyorlar.

Bunun sonucu olarak; 15 Ağustos 1984 'de Eruh ve Șemdinli baskınlarıyla başlayan Terör eylemlerinde, 5 bin güvenlik görevlisi ve 30 bin vatandaşımız hayatını kaybetmiştir.

Yunanistan'ın iktidar partisi PASOK'un milletvekilleri Bekaa'ya giderek Tterörist başına siyasi destek verdiklerini dünya'ya ilan etmişlerdir.

Bu gelişmelerden sonra, Türkiye kararlı davranarak, terörist başının Suriye'den çıkarılmasını isteyince, Yunan makamları devreye girmiş, Kıbrıs Rum tarafının verdiği sahte bir pasaportla, Terörist başı Abdullah Öcalan'ı Kenya'daki Yunan Büyükelçiliğinde saklamışlardır.

Türk güvenlik güçlerinin başarılı bir operasyonu ile ele geçen Terörist başı, Yunanistan'ın sağladığı siyasi ve askeri desteği dünya medyası önünde açıkça itiraf etmiştir. Ayrıca ele geçen dokümanlarla da itirafları doğrulamıştır.

Terör olaylarının en yoğun olduğu 1992 yılında, Yunanistan Genelkurmay Başkanlığının resmi yayın organı olan, Stohos (Hedef) isimli dergide, Megali İdea'nın Türkiye üzerindeki bütün hedefleri yakında gerçekleşecek diye, Türkiye'nin üzerini Yunan Bayraklarının kapladığı bir harita yayınlanmıştır. 


\section{4.- AB'ye girdikten sonra;}

Kıbrıs Rum kesimi, devletler hukukuna aykırı olarak AB'ye alınmıștır. Artık AB üyesi olan Kıbrıs Rum Yönetimi, geçmişte olduğu gibi, Avrupa devletlerinin desteğini alarak, Kıbrıs üzerindeki emellerinin tahakkukuna hız vermiş ve aynen Ellada Sipna kitabında belirtildiği gibi, Türkiye'nin AB 'ye girişi için Kıbrıs'ı koz olarak kullanmaya başlamıştır.

Başta $\mathrm{AB}$ olmak üzere bütün dünya kamuoyunu etkilemek için“Kuzey Kıbrıs'ın işgal altında olduğunu, Türk askeri adadan çıkmadıkça çözümün olamayacağını, Yunan tanklarının Girne'ye kadar ilerleyeceğini ve bütün Kıbrıs'ın bir Elen adası olduğunu, Kıbrıs Rum Yönetimi eski Cumhurbașkanı Papadopulos ve göreve yeni başlayan Cumhurbaşkanı Hristofyas ve Rum Milli Muhafız Ordusu Komutanı olan Yunanlı Korgeneral açıklamaktadırlar.

\section{Megali İdea'ya Rağmen Türk-Yunan Barıșı Sağlanabilir mi?}

Olaylar tarafsız bir gözle incelendiğinde görülür ki Türkiye'nin zayıf bir anında Yunanistan Megali idea'nın hedeflerine ulaşmak için her yolu deniyor ve bu fikrinden hiç vazgeçmiyor.

-O halde tek tarafın, yani Türkiye'nin istemesiyle bir Türk - Yunan barıșı sağlanabilir mi?

- Evet, sağlanabilir. Bu ancak tarih șuuruna sahip Yunanlıları iyi tanıyan ve Megali İdea'yı iyi anlamış Türk devlet adamlanı tarafından sağlanabilir. Bunun en iyi örneğini Atatürk'ün uyguladığı politikada görüyoruz.

Yunanistan'ın dış politikasının, uluslararası politikanın gerekleri karşısında zaman zaman vazgeçilmesi dışında, Megali İdea'ya dayandığını bilen Atatürk'ün,1937 yılında Türk-Yunan ilişkilerine bakıș1 şöyle nakledilmektedir:

"Y1l, 1937'dir. Fethi Okyar, O tarihte Londra Büyükelçisidir. Yaz tatili dolayısıyla Türkiye'ye gelmiş, Çankaya'da çok eski dostu olan Mustafa Kemal'i ziyaret etmektedir... Bu ziyaret sırasında; zamanın Hariciye Vekili Tevfik Rüştü Aras yanlarına gelir ve "Atina'dan yeni geldiğini, Balkan Paktı'nın Sonbahar Toplantısı'nın Ankara'da yapılacağını, Yunan Başbakanı Metaksas ile Atina'da geniş bir konuşma yaptığını ve Yunanistan'la aramızda artık hiçbir mesele kalmadığını" söyler. Mustafa Kemal, "Pekiyi, git bunları Başbakan'a anlat, akșam senin izahatını sofrada hep beraber dinleyelim" der. 
O akşamki sofrada mutadın hilafına Mareşal Fevzi Çakmak'da vardı. Herkes, yakın mazide bu kadar kanlı bir çatışma içinde olduğumuz Yunanlılarla böylesine barıșsever bir yakınlaşmanın asıl mimarı olan Atatürk'e hayranlıklarını ifade eden sözler söylerler. Atatürk bunları dinler ve mealen şöyle der "Arkadaşlar, barış arzuları samimi ve köklü olduğu takdirde, bir ölçüde de olsa muhataba tesir eder. Dünyada iki millet vardır ki, nereden idare edildiği bilinemez. Bunlardan birisi Yunanlılar, birisi de Musevilerdir. Yunanlılar Atina'dan idare edilirler, okyanuslardaki ticaret filolarından hatta İstanbul'daki Rumlar tarafından idare edilirler, kısacası bütün dünyadaki Rumlar tarafından idare edilirler.

Museviler ise, henüz müstakil bir hükümete sahip değillerdir; fakat azami 10 sene içerisinde binlerce senelik ssrarla ve azimle takip ettikleri gayelerine vasıl olacaklardır. Zira bugün Musevilerin nüfuzları, büyük zannedilen birçok devletlerin üstündedir.

Biz Türkler, tarihimiz ve coğrafyamız olarak bu iki milletin bünye ve gayelerini hakiki çehresi ile her zaman bilmek ve bunu hatırda tutmak mecburiyetindeyiz" der ve sözlerini şöyle bitirir; "Şüphesiz ki, Türk-Yunan dostluğu lüzumlu ve faydalıdır. Ancak bizim Yunanlılar'ı bu dostluğa her zaman zorlayabilecek güce sahip olmaklığımız şartı ile. ${ }^{14}$

\section{SONUÇ}

Bugünkü Yunanistan'ın 1830 yllında tarih sahnesine çıkışından itibaren, Avrupa devletlerinin; "Doğu Sorunu" adını verdikleri, Türkleri Anadolu'dan atmak, Boğazlara sahip olmak, projesini tatbik ettirmek için, Yunanistan'ı kullandıklarını; Yunanistan'in ise; Megali İdea'sını tahakkuk ettirmek için bu göreve gönüllü talip olduğunu görüyoruz.

Yunanistan, daima Avrupa Devletleri'nin desteği ile hep Doğuya doğru, yani Türkiye aleyhinde genişlemiş, Türkler Balkanlardan çekildikten sonra, hiçbir zaman batı veya kuzeye genișlemesi olmamıștır. Bu da gösteriyor ki, Avrupa Devletleri Yunanistan'a sadece Türkiye aleyhine genişleme için destek vermektedirler.

Yunanistan, tarih boyunca, hep Türkiye'nin zayıf anını kullanarak Megali İdea Hedeflerine ulaşmıştır. Günümüzde ise; Yunanistan, Türkiye'yi zayıf düşürecek ve parçalayacak tertipler içine girmiş, bunu psikolojik harp metotlarıyla, Ortadoğu'da ve $A B$ içinde müttefikler ve destekler bularak yapmış, Megali İdea'nın son birkaç hedefini de ele geçirmek istemiştir

14 M.Derviş Manizade. 65 Yıl Boynanca Kıbrıs. Yazdıklarım - Söylediklerim. Kıbns Türk Kültür Derneği (Istanbul Şubesi ) Yayınlan, No:9 Istanbul -1993. s.265-266 
O halde Türkiye olarak ne yapılmalıdır ki, Yunanistan'ın Megali İdeasına rağmen, kalıcı bir Türk-Yunan Barışı sağlansın.

Türk devletinin en zayıf anında ve Yunanistan'ın Megali idea hedeflerine ulaşmak üzere bulunduğu bir anda buna mani olan, Türklüğü ve Anadolu'yu kurtaran büyük asker ve eşsiz devlet adamı Mustafa Kemal Atatürk'ün işaret ettiği; "Yunanistan'1 dostluğa zorlayabilecek güce sahip olmak şartı" daha açık bir şekilde ifade edilecek olursa;

-Yunanistan'ın Türkiye aleyhindeki politik girişimlerini bertaraf edecek kadar bilinçli siyasi kadrolardan meydana gelen bir " Siyasi güç"ü oluşturmak,

- Bir iç tehdide ve aynı anda birkaç cephede birden, savaşma tehlikesine rağmen, Yunanistan'ın askeri tehdidini bertaraf edecek kadar bir“ Askeri güç" ü oluşturmak,

- Dışa bağımlı olmayan ve en az Yunanistan'dan üstün bir ekonomik seviyeyi sağlayacak "Ekonomik güç" ü oluşturmak,

—Bütün Milletin ve özellikle yöneticilerin Megali İdea tehdidine karşı bilinçlendirilip yüksek bir milli şuura sahip olan bir "Psikososyal güç"ü oluşturmak ve

- Son teknolojileri ülkemizde geliştirecek ve kullanabilecek kadroları ve alt yapıyı sağlayan bir "Teknolojik güç"ü oluşturmak, şarttır.

Yunanistan'la devamlı bir barıșın sağlanması ve Türk-Yunan ilişkilerinin barış içinde devam etmesi için yukarıda sayılan hedeflerin gerçekleşmesi gerekmektedir.

Atatürk'ün Türk-Yunan ilişkileri hakkındaki görüşünün isabeti, yaşanan olaylarla kanıtlanmıştır.

\section{KAYNAKÇA}

ANDRE, Prens, Felakete Doğru, Erkan-1 Harbiye-yi Umumi-ye Matbaası, İstanbul1933.

ATATÜRK, M.Kemal, Nutuk, ADTYK, Atatürk Araştırma Merkezi Yayını, Ankara-1992.

BRITANNICA, Encylopedia, William Benton, Publisher, Scotland-1768, USA1970. 
BAŞER, Cem, Yunan Oyunu, İstanbul-1988.

DENDRINOS, Andrea, Ellada Sipna, 1nci Bask1; Atina-1984, 2nci Baskı;1995.

HATIPOĞLU, M.Murat, Yunanistan'daki Gelişmelerin Işı̆̆ında Türk-Yunan İlişkilerinin 101 yll (1821-1922), TKAE Yayını, Ankara-1988.

KAMIL, Sadrazam Paşa, Tarih-i Siyasi Devlet-i Aliye-i Osmaniye, Matbaa-i Ahmet İhsan, İstanbul-1325.

KOCABAŞ, Süleyman, Tarihte ve Günümüzde Türk-Yunan Mücadelesi, Bayrak Yayınları, İstanbul-1984.

KODAMAN, Bayram, II nci Abdülhamit Devri Doğu Anadolu Politikast. İstanbul1987.

LAROUSSE, Büyük, Sözlük ve Ansiklopedisi, Gelişim Yayınlan A.Ş. İstanbul1986.

LAROUSSE, Meydan, Büyük Lûgat ve Ansiklopedi, Paris-1960, Meydan Gazetecilik ve Neşriyat Ltd. Şti. İstanbul-1970.

MANIZADE, M.Derviş, 65 yıl Boyunca Kıbrls, Yazdıklarım-Söylediklerim, Kıbrıs Türk Kıbrıs Türk Kültür Derneği (İstanbul Şubesi) Yayınlan, İstanbul-1993.

SMITH, Michael Llewellyn, Yunan Düşü, Ayraç Yayınlan, Ankara-2002.

ŞAHIN, M.Süreyya, Fener Patrikhanesi ve Türkiye, Ötüken Yayını, İstanbul-1980.

UYSAL, Mehmet, Aldatma Ile Örtülen Yunan Yayılması, Harp Akademisi Basımevi, İstanbul-1996. 
EKLER :

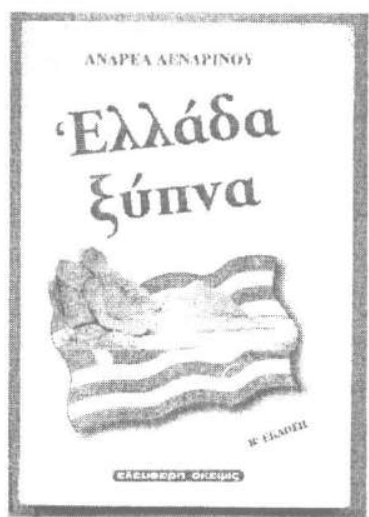

Şekil-1; Ellada Sipna (Yunanistan Uyan) kitabının birinci ve beșinci baskılarının kapakları 


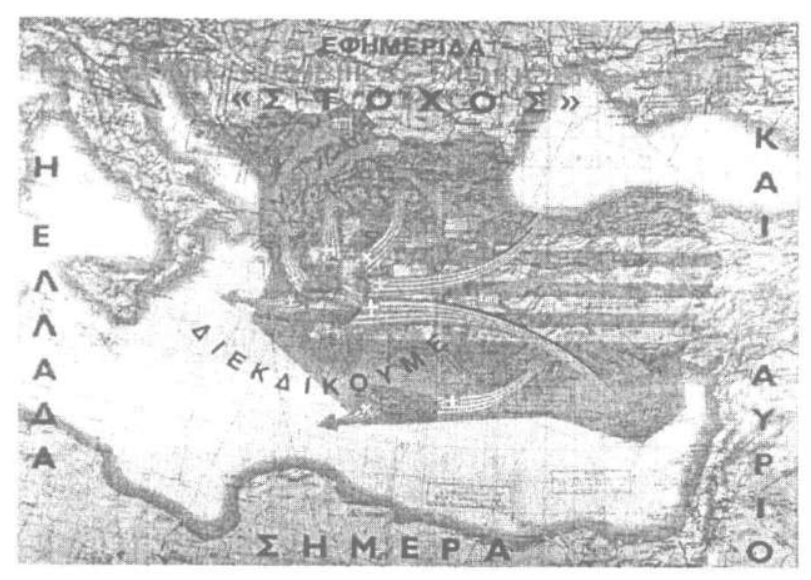

Sekil-2; Yunan Genelkurmay Başkanlığının resmi yayın organı Stohos (hedef) adlı aylık askeri derginin, 1992 yılında yayınlanan sayısında, Türkiye üzerindeki Megali İdea hedeflerinin yakında gerçekleșeceği gösterilmektedir. 